\title{
Do rebentar da imagem: releitura do epílogo de Uma faca só lâmina (1955) \\ a partir da reavaliação da fortuna crítica cabralina
}

\author{
From the bursting of the image: reinterpretation \\ of the epilogue of Uma faca só lâmina \\ (1955) from the reassessment of the \\ Cabral's critical fortune
}

Erick Monteiro Moraes ${ }^{1}$

RESUMO

Dentre os muitos pontos consensuais da fortuna crítica dedicada à obra de João Cabral de Melo Neto, encontra-se a ideia de que A educação pela pedra (1966) seja um divisor de águas, zênite da carreira do "poeta-engenheiro". Essa ideia pressupõe que, tal qual o próprio Sol, João Cabral enquanto poeta emergiria da madrugada onírica de Pedra do Sono (1942), até que, acendendo à medida que ascendesse, atingisse o apogeu da clareza e da claridade: o meio-dia de A educação pela pedra. Logo depois, sua obra perderia "algo da contundência solar" (SANTIAGO, 1982, p. 44), seja pelo supostamente menor grau de obsessão arquitetônica em relação ao livro como unidade de sentido, seja pela hipertrofia do "contar de si", i.e., do veio autobiográfico. Na contramão dessa narrativa, este artigo tenciona, se não descartar inteiramente a teleologia da obra (e sua consequente dicotomia), ao menos destacar suas fissuras. Nesse intuito, busca-se reavaliar "As incertezas do sim" (1982), texto de Silviano Santiago que, inobstante o fôlego curto e o sabor de resenha, pode ser considerado paradigmático não só pelo poder de influência de seu autor no campo da crítica especializada de poesia mas também pela maneira categórica com a qual reproduz o pressuposto teleológico. Em um segundo momento, empreende-se uma revisão do epílogo de Uma faca só lâmina (1955) a fim de ressaltar, justamente em um dos poemas mais representativos da "fase de ascensão", as marcas que Santiago toma por exclusivas da suposta "fase de ocaso".

Palavras-chave: João Cabral de Melo Neto; Silviano Santiago; Uma faca só lâmina.

1 Pontifícia Universidade Católica do Rio de Janeiro/RJ. E-mail: erickmonteiromoraes@gmail.com 
Among the many points of consensus regarding the critical fortune dedicated to the work of João Cabral de Melo Neto is the idea that A educação pela pedra (1966) is a watershed, the zenith of the poet's career. This idea assumes that, just like the Sun itself, João Cabral as a poet would emerge from the oneiric dawn of Pedra do Sono (1942), until, lighting up as ascending, he reached the pinnacle of clarity and lucidity: the midday of A educação pela pedra. Soon after, his work would lose "something of its solar force" (SANTIAGO, 1982, p. 44), either by the supposedly lower degree of architectonic obsession with the book as a unit of meaning, or by the hypertrophy of the "telling of yourself", i.e., the autobiographical vein. Countering this narrative, this article intends, if not to entirely discard the teleology of the work (and its consequent dichotomy), at least to highlight its fissures. In this sense, it seeks to read "As incertezas do sim" (1982), a text by Silviano Santiago that, despite its shortness, can be considered paradigmatic not only because of its author's power of influence in the field of specialized poetry criticism, but also because of the categorical way in which it reproduces the teleological assumption. In a second moment, a revision of the epilogue of Uma faca só lâmina (1955) is undertaken in order to highlight, precisely in one of the most representative poems of the "ascension phase", the marks that Santiago takes as exclusive of the supposed "sinking sun phase".

Keywords: João Cabral de Melo Neto; Silviano Santiago; Uma faca só lâmina. 
entre os muitos pontos consensuais da fortuna crítica da obra de João Cabral de Melo Neto reside a ideia de que $A$ educação pela pedra [1966] $]^{2}$ seja um divisor de águas, zênite da carreira do "poetaengenheiro". Trata-se de um pressuposto que seduz o pesquisador, antes de mais nada, porque permite que se descreva a trajetória do poeta por meio de imagem tão característica do seu universo poético que é como se o discurso crítico desdobrasse a obra da qual se ocupa ${ }^{3}$. Pois tal como o Sol, João Cabral emergiria da madrugada onírica de Pedra do Sono [1942], até, acendendo à medida que ascendesse, atingir o apogeu da clareza e da claridade: o meio-dia de A educação pela pedra. Logo depois, sua obra perderia "algo

2 As datas entre colchetes referem-se ao ano de publicação da obra citada, não remetendo para as referências finais.

3 Aludo à concepção romântica de crítica literária segundo Walter Benjamin (1993). A proposta benjaminiana implica uma dupla leitura desta expressão, a um só tempo como genitivo objetivo e subjetivo. Assim, se compete à crítica moderna desdobrar poeticamente o germe crítico imanente à obra literária, então apropriar-se de imagem intrínseca à poética cabralina - o Sol - a fim de descrever o processo evolutivo da obra consistiria num autêntico procedimento de crítica poética. 
E. M. Moraes

Do rebentar da imagem: releitura do epílogo de Uma

faca só lâmina (1955) a partir da reavaliação da fortuna crítica cabralina

Revista Letras, Curitiba, UFPR, n. 102, pp. 94-115, jul./dez. 2020 ISSN 2236-0999 (versão eletrônica) da contundência solar" (SANTIAGO, 1982, p. 44), seja pelo supostamente ${ }^{4}$ menor grau de obsessão arquitetônica em relação ao livro como unidade de sentido, seja pela hipertrofia do "contar de si”, i.e., do veio autobiográfico.

Além disso, vale ressaltar que a obra cabralina parece especialmente propensa a "divisores de águas", o que se verifica até mesmo em projetos editoriais, desde a metáfora-título da coletânea Duas águas $(1956)^{4}$ até a bissecção da última coletânea anterior à morte do poeta: Serial e antes e $A$ educação pela pedra e depois $(1997)^{5}$. Neste caso, é provável que o leitor de Cabral não se surpreenda ao deparar-se com A educação pela pedra enquanto "vértice de corte", embora talvez estranhe que o livro-zênite esteja coligido não no primeiro volume (o da "fase de ascenso"), mas no último (o da "fase de declínio"). Com vistas a preservar a coerência da narrativa teleológica, talvez fosse possível recorrer ao dito popular e, invertendo-o, dizer que o Sol brilha mais alto justo quando começa a se pôr. Ou assim poderia argumentar um defensor da hipótese dos "dois Cabrais".

Às "evidências" editoriais, soma-se o fato de a maioria dos trabalhos canônicos da fortuna crítica ter sido escrita entre a segunda metade da década de 1960 e a primeira da década de $1980^{6}$. Isso inevitavelmente reforça a ideia de que, se a obra não se fechava com $A$ educação pela pedra [1966], ao menos certa etapa havia sido concluída, o que autorizaria a incursão crítica. Diante disso, é possível aventar duas hipóteses extremas em relação ao projeto cabralino pós-1966: ou não se altera - e os livros posteriores em nada escapariam às análises canônicas -, ou se renova por completo, demandando novo impulso crítico. Embora radicalmente opostas, ambas se assemelham não só pela radicalidade mas também pelo "conservadorismo", uma vez que não põem em questão a teleologia da obra, ou seja, tomam por dada a progressiva hipertrofia da razão desde Pedra do sono [1942] até A educação pela pedra [1966], divergindo apenas quanto à continuidade desse projeto a partir de 1966.

A contrapelo, o presente artigo busca, se não descartar de todo a teleologia da obra (e sua consequente dicotomia), ao menos destacar suas fissuras. Nesse intuito, recorre-se a "As incertezas do sim" (1982), texto de Silviano Santiago que, apesar do fôlego curto e do sabor de resenha, pode ser considerado paradigmático não apenas pela enorme projeção do autor no

4 O título remete a uma dicotomia que, supostamente, atravessa a obra cabralina: entre poesia do mundo (transitiva) e poesia da poesia (intransitiva). Sobre sua validade, cf. OLIVEIRA, 2008.

5 A notar que essa divisão reproduz uma anterior: em 1968, ano em que Cabral elegeuse à Academia Brasileira de Letras, foi lançada a coletânea Poesias Completas, que coligiu toda sua obra até então, desde Pedra do Sono até A educação pela pedra. Em 1988, os livros lançados após 1968 foram reunidos em coletânea intitulada Museu de Tudo e Depois. Desse modo, a obra encontrava-se enfim reunida, mas, ao mesmo tempo, bifurcada.

6 Haroldo de Campos [1967]; Luiz Costa Lima [1968]; Benedito Nunes [1971]; José Guilherme Merquior [1972]; João Alexandre Barbosa [1974]; Marta Peixoto [1977]; e Antonio Carlos Secchin [1982]. 
campo da crítica especializada como também pelo modo deveras assertivo senão dogmático - com que ele adere à premissa teleológica. Em um segundo momento, empreende-se uma revisão da leitura dominante de Uma faca só lâmina - mais precisamente do epílogo - a fim de evidenciar, justamente em um dos poemas mais representativos do percurso de "ascensão solar", as marcas que Santiago destaca como exclusivas da suposta "fase de ocaso".

\section{"As incertezas do sim"}

Em antológico ensaio intitulado "O entre-lugar do discurso latinoamericano" [1978], Silviano Santiago assevera que, para o intelectual latinoamericano, "falar, escrever, significa: falar contra, escrever contra" (2000, p. 17). Pode-se afirmar que, no presente artigo, essa exortação se volta obviamente deslocada de contexto - contra quem a cunhou, uma vez que se avalia "As incertezas do sim" (1982), escrito por Santiago à ocasião do lançamento de A escola das facas [1980].

O ensaio se inicia ao destacar, do então mais novo livro de Cabral, sua suposta novidade, qual seja, a hipertrofia do sujeito lírico: "um veio autobiográfico original irrompe no discurso poético cabralino, antes tão impessoal e adulto" (SANTIAGO, 1982, p. 41). Nada de polêmico até esse juízo, que é ponto pacífico entre os principais críticos que se detiveram no volume em questão:

\footnotetext{
O poeta incute no texto uma perspectiva até então praticamente inexistente: a do próprio sujeito lírico enquanto ser histórico. Pela primeira vez de forma sistemática, o "eu" se confere um lugar explícito no corpo do poema. De sujeito camuflado sob a terceira pessoa gramatical (o poeta se contava pelo que via fora de si), João Cabral passar a expor o personagem de si mesmo imerso na matéria que conta. (SECCHIN, 2015, p. 291).

O mais notável recomeço que experimenta nessa sua última fase a obra de João Cabral é o surto memorialístico em Escola das facas, Agrestes e Crime na Calle Relator (1987), surto que implica suspender a anterior economia da subjetividade, restabelecendo de maneira discreta, a afirmação do Eu. (NUNES, 2007, p. 137).
}

Em seguida, o autor identifica como "autoritarismo estético" a despersonalização artística, que, segundo ele, havia sido até então "a marca original de Cabral": 
E. M. Moraes

Do rebentar da imagem: releitura do epílogo de Uma faca só lâmina (1955) a partir da reavaliação da fortuna crítica cabralina
Esse efeito de despersonalização artística e de autoritarismo estético levou Cabral a construir poemas onde as incertezas no trato com a realidade são excluídas, em favor de verdades irrefutáveis. Há em Cabral uma linguagem (e, portanto, um conhecimento) que exclui a dúvida; uma linguagem poética clara e transparente, certa e solar, impecável na sua lógica negativa, que possibilitou poemas dogmáticos e excludentes. (SANTIAGO, op. cit., p. 43)

O crítico acredita, pois, que a ausência de um Eu explícito no corpo do poema implica o "pecado" da "vontade de objetividade" tão abominado pela crítica de inspiração "pós-estruturalista". Onde Santiago enxergou "autoritarismo estético", Costa Lima vislumbrara, em Lira e antilira [1968] - logo, uma década antes —, o exato oposto, ou seja, um procedimento contradogmático na medida em que problematiza as relações entre palavra e coisa, poesia e mundo e, até mesmo, história e História: "O pôr em xeque a posição da emocionalidade no poema termina por levar à discussão do tipo de elo existente entre a palavra poética e a realidade contemporânea" (LIMA, 1995, p. 26). Esse entendimento veio a ser respaldado por Secchin, já nos anos 1990, na seguinte magistral descrição da "vontade de objetividade" cabralina:

[...] podemos acercar-nos das configurações específicas do universo cabralino, não sem antes examinar o registro pelo qual ele se quer demonstrar: o da objetividade. Em que consiste a objetividade num poema? Para tentar algumas respostas, recorramos à divisa predileta de Cabral, reiterada em inúmeros depoimentos: a poesia deve "dar a ver". Tal sintagma pressupõe um ponto de visibilidade ideal e a necessidade de remover obstáculos que a estejam toldando. O problema já se instala no fato de que o instrumento apto a aclarar a percepção é o mesmo que serve para encobri-la: a palavra. A partir de quais critérios, portanto, podemos avalizar uma percepção como mais isenta e exata do que outra? A simplificação didática da expressão "poesia objetiva" esconde uma série de mal-entendidos e de contradições, sobretudo se nos ativermos a parâmetros de natureza formal, considerando, por exemplo, que seria objetivo o texto que não contivesse as marcas linguísticas da primeira pessoa [...]. Toda obra revela simultaneamente a percepção e o percebido, seja a percepção exterior ou interna, seja a percepção de uma pedra ou o mais inefável dos sentimentos. A objetividade plena pressuporia eliminar o foco de enunciação, pois este se deixa repercutir inevitavelmente naquilo que está capturando. Dar a ver não é deixar o objeto objetivamente falar, é escolher estratégias propícias a uma simulação de objetividade, em que as impregnações mais visíveis do sujeito se 
camuflem em prol de uma cena em que os objetos pareçam falar de si, mas sempre por meio do sotaque de quem os vê. Por mais que o artista deseje, a escrita do mundo não é autógrafa. A fé num registro descontaminado foi enterrada com a hipostasia naturalista; destruída a fé, resta a simulação (SECCHIN, 2015, p. 401-2).

Além disso, como poderia João Cabral ser autor de uma poesia excludente e dogmática, autoritária e avessa à dúvida, se é justamente ele quem congrega, ao menos desde seu primeiro livro, antinomias como sono e lucidez, acaso e trabalho, surrealismo e cubismo? Em artigo recente, Solange Fiuza resgata o texto fundador da recepção crítica de João Cabral no Brasil, qual seja, a resenha escrita por Antonio Candido pouco após a publicação de Pedra do Sono [1942]:

Para Candido [...], o construtivismo, a organização consciente do material, não resulta em um "edifício racionalista" ou em uma poesia apenas cubista, mas na aliança entre "a ordenação da inteligência" e o "que há de mais essencialmente espontâneo no homem", na fusão de duas correntes diversas em uma poesia pessoal, original. (FIUZA, 2019, p. 3).

A autora lembra ainda que o próprio poeta, posteriormente, fez questão de sobrepesar, dentre as características destacadas por Candido, aquelas que mais lhe agradavam: "composição", "controle", "trabalho consciente". Depois disso, decerto influenciados pela "autoridade do autor", muitos críticos viriam a respaldar a hipertrofia do racional e de seus elementos afins:

\begin{abstract}
No seu belo estudo Realidad y forma en la poesía de Cabral de Melo (separata da Revista de Cultura Brasileira, no 8, Madri, março de 1964), Angel Crespo e Pilar Gómez Bedate comentam: "Lo que este hombre (o engenheiro) está haciendo verdaderamente no es soñar, sino pensar, proyectar". Esta análise parece supor que o emprego de sonho e sonhar neste poema é uma quase impropriedade, uma espécie de reminiscência de uma fase anterior no pensamento do poeta - o qual teria "progredido" da valorização do onírico para o elogio da lucidez antionírica. (MERQUIOR, 1997, p. 94).
\end{abstract}

Merquior é certeiro em sua denúncia da teleologia subjacente à interpretação de "O engenheiro" apresentada por Angel Crespo e Pilar Gómez Bedate. Em seguida, propõe uma leitura que prescinde da hipótese evolutiva:

Talvez nossa leitura não esteja de acordo com a bem divulgada ideia de que $O$ engenheiro constitui uma preparação decidida de 
E. M. Moraes

Do rebentar da imagem: releitura do epílogo de Uma faca só lâmina (1955) a partir da reavaliação da fortuna crítica cabralina

Revista Letras,

Curitiba, UFPR,

n. 102, pp. 94-115,

jul./dez. 2020

ISSN 2236-0999

(versão eletrônica) uma poética da pura lucidez, do puro cálculo, aguerridamente opostos a toda receptividade. (ibid., p. 96).

Além de Candido e Merquior, pode-se citar Haroldo de Campos, Benedito Nunes e João Alexandre Barbosa entre os grandes nomes que souberam notar ${ }^{7}$ que "a poesia de João Cabral é uma poesia agônica: sempre a mesma e sempre diferente, repete em cada um de seus momentos a experiência de um perpétuo recomeço" (NUNES, 2007, p. 136) ${ }^{8}$. De Barbosa, vale destacar "A poesia crítica de João Cabral" (2002), ensaio em que o autor observa como a "água" da poesia crítica de uma dada realidade corre não paralelo, mas junto, à "água” da poesia crítica da própria linguagem. Trata-se, afinal, de argumento inverso ao de Santiago, para quem a crítica da realidade, por contundente, é a fortiori dogmática.

Santiago parece, assim, vítima de seu próprio diagnóstico:

Talvez o poema recente de Cabral perca algo da contundência solar anterior, certamente a sua nova "mensagem" pode perder-se nos labirintos das dúvidas, mas a poesia se enriquece, no entanto, com uma visão diferenciada e complexa da realidade, porque essa visão não é mais simplificada, excludente e autoritária. (1982, p. 44-5).

Assim, falta-lhe, quem sabe, "uma visão diferenciada e complexa" (ibid., p. 44) da poesia cabralina anterior aos anos 1980. Na segunda parte deste artigo, defende-se que o juízo de Santiago em relação à suposta "primeira fase" de Cabral não se sustenta ante uma leitura detida da obra, recaindo no perigo para o qual alerta Marcos Siscar em relação à percepção cristalizada de certa linhagem crítica: "A ideia de um intelectualismo que exclui o sujeito é uma ideia pré-analítica e constitui uma visão mais próxima de sua situação 'escolar', por assim dizer" (2018, p. 611).

Ao menos no que se refere a $A$ escola das facas, a visão de Santiago "não é mais simplificada, excludente e autoritária" (SANTIAGO, loc. cit.),

7 As mais das vezes, como é o caso com Santiago, aderir à premissa teleológica implica reproduzir uma "caricatura" da obra cabralina - de uma poesia a cada livro mais "impessoal", "cerebral", "objetiva", "planejada" (limito-me, ao gosto de Cabral, apenas a quatro adjetivos). Como já dito, essa impressão contou com o próprio poeta dentre seus primeiros promotores. Cabe notar também que os demais críticos que ora cito como contraponto ao texto de Silviano também colaboraram, em alguma medida, para a consolidação da narrativa teleológica. Tais colaborações limitaram-se, contudo, a juízos quase sempre pontuais e matizados por outros - os que aqui comparecem - que relativizam e até mesmo "redimem" os primeiros. Silviano, por outro lado, reproduz sem ressalvas essa narrativa no que tange a obra anterior a 1980, o que justifica a contraposição aqui estabelecida.

8 Este juízo de Nunes vai ao encontro da percepção de Haroldo de Campos em "O geômetra engajado": "sua poesia [de Cabral] é dialética não para o conforto de alguma síntese ideal, hipostasiada no absoluto, mas pela guerra permanente que engendra entre os elementos em conflito, à busca de conciliação, e onde o possível se substitui normativamente ao eterno" (CAMPOS, 2006, p. 84). 
pois apresenta-se capaz de notar as sutilezas que desde sempre estruturaram a obra cabralina:

Com A Escola das Facas, a poesia de Cabral desdogmatiza-se. A própria incerteza no trato com a realidade começa a habitar o campo semântico do poema, exprimindo-se em palavras e construções onde ficam pouco nítidas as diferenças. No processo de desdogmatização, as fronteiras rigorosas de significado perdem a nitidez, diluem-se, contaminando áreas que antes não teriam sido afins (antes foram opostas e por isso excludentes). (ibid., p. 43).

A destacar outra marca cabralina condenada por Santiago: "as fronteiras rigorosas de significado" (ibid., p. 43). Trata-se, novamente, de elemento consensual entre os críticos: "Em João Cabral, [...] a vontade de realismo se traduz na predominância do denotativo" (LIMA, p. 44); ou "A poética de desconfiança perante o universo de conotações é traço marcante da arte cabralina" (SECCHIN, op. cit., p. 153). Outra vez, se para Santiago essa marca está a serviço da exclusão das incertezas no trato com a realidade, para Secchin trata-se do diametralmente oposto:

A enumeração das palavras "impossíveis de poema" (podemos falar, a propósito de João Cabral, numa "poética da especificação") é contradita pela própria utilização dos vocábulos "interditos". Nesse jogo ambíguo repousa (ou se inquieta) a rede do texto: ela utiliza certos signos (ouro, seda) na expectativa de remover-lhes as conotações já sedimentadas pelo uso. Para combater a metáfora-clichê, o poeta percorre, inicialmente, um trajeto de esvaziamento do signo, desobstruindo-o daquilo que o costume linguístico estatuíra ser sua "verdade" (op. cit., p. 152-3).

Em vista disso, é lícito afirmar que a primazia do denotativo sempre esteve a serviço não do estabelecimento de verdades incontestes, mas da relativização e da dúvida9.

Paradoxalmente, Santiago reproduz de modo acrítico a narrativa teleológica senão para destacar, de modo perspicaz, a potência dialética de $A$ escola das facas:

9 Inclusive, segundo Secchin, reside aí uma das diferenças teóricas fundamentais entre a poética concretista e o projeto pessoal de Cabral: "João Cabral não compartilha esse triunfalismo [dos concretistas], essa jubilosa certeza do verbo. Na sua obra, ao contrário, o vínculo entre palavra e realidade será sempre lacunoso, claudicante. Daí a necessidade de contínuas versões e leituras com que cerca um objeto, criando metáforas "até certo ponto", metáforas de vigência restrita, convocadas para serem suprimidas pela denúncia da sua própria insuficiência. Temos, pois, a palavra como assédio maciço a uma realidade inesgotável, a uma plenitude ilegível no todo, mas que deixa entrever seus restos no poema." (2015, p. 400-1). 
E. M. Moraes

Do rebentar da imagem: releitura do epílogo de Uma faca só lâmina (1955) a partir da reavaliação da fortuna crítica cabralina
Remédio e/ou veneno, sim e/ou não, desdogmatiza-se a poesia de Cabral através da dúvida, e, ao desdogmatizar-se, pode o "sertão do não", caro ao poeta na sua crítica social, confluir com o anteriormente excluído "sertão do sim". (p. 44).

O “duelo à pernambucana" é o novo estágio da poesia cabralina. Nesta fase, somam-se ao não e ao certo o sim e a incerteza. Cabral adentra-se pelo sim e pela incerteza, sem perder na cordialidade a luta, sem desvalorizar o inimigo pela sua inexistência, sem anular o combate pela falta de facas. Ou de escolas. (p. 45).

Essa estruturação binária a que se refere Santiago (e que em sua visão adquire contornos maniqueístas) atravessa toda a obra cabralina. De um lado, o "não", a certeza, a morte, o absoluto; do outro, o "sim", a incerteza, a vida, o contingente. Na contramão de Santiago e de certa recepção da fortuna crítica, defende-se aqui a hipótese de que o "não" jamais exclua o "sim". Em Cabral, niilismo e vitalismo são opostos complementares, ainda que este seja apenas uma ilha, precária e provisória, engastada na vastidão daquele. E justamente porque Santiago elege a "faca" ${ }^{10}$ como símbolo-mor do que acredita ser uma poesia do "não", excludente e dogmática, fechada à diferença e indiferente à incerteza, proponho-me a seguir a dar a ver o "sim" dentro do "não" de Uma faca só lâmina.

\section{As incertezas da Faca}

\author{
Aderir ao próprio texto \\ Com o corpo, escrever com o \\ Corpo; \\ Exato que nem uma faca. \\ Murilo Mendes \\ (provando que o número, \\ sim, e a geometria \\ podem o erotismo \\ do livre lirismo; \\ que a régua, só talo \\ sem miolo ou pétala \\ - outra natureza -,
}

Revista Letras,

Curitiba, UFPR,

n. 102, pp. 94-115,

jul./dez. 2020

ISSN 2236-0999

(versão eletrônica)
10 "A metáfora privilegiada, na poesia de Cabral, para essa voz clara, agressiva e dogmática, é a 'faca', faca que na sua contundência chega a ser 'só lâmina”' (ibid., p. 42). 


$$
\begin{aligned}
& \text { tem cor e perfume } \\
& \text { que penetram fundo } \\
& \text { e que acendem partes } \\
& \text { em nós secretíssimas, } \\
& \text { do mais alto fogo) }
\end{aligned}
$$

\section{Eucanaã Ferraz}

O epílogo de Uma Faca só lâmina constitui uma retrospectiva “del cammin" ontológico-conceitual percorrido ao longo dos 320 hexassílabos que lhe antecedem. E assim como a voz lírica admite deter-se mais longamente na "lâmina" por ser ela, dentre todas as imagens, a que melhor condensa a angústia, esta leitura se limita ao epílogo por considerá-lo, em sua retrospecção, o segmento mais representativo do poema. Ei-lo:

De volta dessa faca,

amiga ou inimiga,

que mais condensa o homem

quanto mais o mastiga;

de volta dessa faca

de porte tão secreto

que deve ser levada

como o oculto esqueleto;

da imagem em que mais me detive, a da lâmina, porque é de todas elas certamente a mais ávida;

pois de volta da faca se sobe à outra imagem, àquela de um relógio picando sob a carne,

e dela àquela outra, a primeira, a da bala, que tem o dente grosso porém forte a dentada

e daí à lembrança que vestiu tais imagens e é muito mais intensa 
E. M. Moraes

Do rebentar da imagem: releitura do epílogo de Uma faca só lâmina (1955) a partir da reavaliação da fortuna crítica cabralina do que pôde a linguagem,

$$
\begin{aligned}
& \text { e afinal à presença } \\
& \text { da realidade, prima, } \\
& \text { que gerou a lembrança } \\
& \text { e ainda a gera, ainda, } \\
& \text { por fim à realidade, } \\
& \text { prima, e tão violenta } \\
& \text { que ao tentar apreendê-la } \\
& \text { toda imagem rebenta. }
\end{aligned}
$$

(MELO NETO, 1997a, p. 194-5).

Em 1971, Benedito Nunes publica, como volume integrante da coleção Poetas Modernos do Brasil, da Editora Vozes, o livro João Cabral de Melo Neto, que viria a se tornar um dos mais referenciados estudos sobre a obra do pernambucano. No sexto capítulo, o crítico-filósofo trata de Uma faca só lâmina, sobre cujo epílogo comenta:

Devido à natureza simbólica da linguagem e ao horizonte perceptivo que a circunscreve, ambos assumidos pela poética de João Cabral, a caça às imagens, sempre deceptiva, mas sempre exigida pelo caráter multissimbolizável da realidade, é como a caça ao Snark. Quanto mais se amplia a rede verbal de que é feito e com que se tenta caçá-lo, mais ele escapa através de suas malhas. Esse paradoxo da linguagem, que a poesia aviva e que nela se extrema, alimentando a inquietação do caçador, já está dado no próprio título do poema. Pois uma faca só lâmina — sem cabo - vem a ser uma imagem da ausência e da incompletude, que mais aumentam quanto maior o golpe com que a faca da linguagem recorta as coisas e penetra na sua carnadura perceptiva, feita de mil camadas verbais. (NUNES, 2007, p. 76).

Nunes, por meio da metáfora da caça ao Snark, enfatiza a natureza escorregadia da realidade. Devido a essa propriedade, todo ímpeto por apreender o real não passaria mesmo de uma tentativa - tentativa essa que resulta, cabe ressaltar, "sempre deceptiva", decepcionante. Além disso, tal fracasso inevitável é tanto mais evidente quanto mais preciso e poderoso for o instrumento empregado. Em outras palavras, a linguagem é um buraco - ou, ainda, areia movediça - em que mais se afunda quanto mais se tenta escapar.

No ano seguinte, sob a pena de Merquior, vem a lume $A$ astúcia da Mímese, cujo maior capítulo ("Nuvem Civil Sonhada") tornou-se outro dos mais importantes estudos da poética cabralina. No subcapítulo em que trata
Revista Letras,

Curitiba, UFPR,

n. 102, pp. 94-115,

jul./dez. 2020

ISSN 2236-0999

(versão eletrônica) 
especificamente de Uma faca só lâmina, Merquior recupera alguns trabalhos predecessores que haviam defendido a tese de que o poema tematiza a insuficiência da linguagem:

\begin{abstract}
A propósito destas quadras, O. M. Garcia [...] comenta: "Essa 'lembrança', e essa 'realidade, prima’ não são facilmente diagnosticadas, mas temos certeza de que o fato - ponto-de-sugestão ou ponto-de-partida para o poema de natureza afetiva, amorosa ou moral - qualquer que seja revestiu-se de pungência tal, que se tornou impossível expressá-lo em linguagem organizada: 'Toda imagem rebenta' quando tenta revestir tais sentimentos". O comentário está perfeitamente de acordo com a tese do autor, segundo a qual o grande tema do lirismo cabralino seria a insuficiência da linguagem, o sentido dos inania verba. (MERQUIOR, 1997, p. 168).
\end{abstract}

De fato, a tese da insuficiência da linguagem não parece senão "fora do lugar" em se tratando de um dos poetas, de todo o cânone brasileiro, mais avessos às premissas do Romantismo (ou, ao menos, do Romantismo em situação "escolar") ${ }^{11}$. Merquior propõe, então, uma interpretação de inspiração heideggeriana do epílogo:

Ele não concebe a linguagem como insuficiente, e sim a realidade - a realidade prima isto é, o Ser em seu fundamento último - como inapreensível: o que, por paradoxal que pareça, não é a mesma coisa. O Ser não é inapreensível de maneira absoluta; longe disso, sua essência é manifestar-se. Mas ele é incaptável de maneira dialética, porque, manifestando-se não se esgota jamais em nenhuma manifestação particular. Nestas condições, a linguagem não é impotente (ao contrário), uma das afirmações mais célebres do novo pensamento ontológico é a de que "a linguagem é a casa do Ser" - mas, ao mesmo tempo, ela foi sempre, e sempre será, impotente. Pensado no horizonte do tempo, nosso paradoxo se dissolve. (ibid., p. 169).

Trata-se, pois, de uma impotência qualificada da linguagem. Isso significa que, embora a apreensão última e definitiva da realidade não seja possível, alguma apreensão é, sim, possível, ainda que precária e provisória. Essa interpretação, que em vias gerais vai ao encontro da leitura de Nunes, finda por levá-la além na medida em que, mais sofisticada, não apenas dá a

11 O abuso das reticências pelos autores românticos do século XIX, por exemplo, pode ser compreendido justamente como índice da premissa da insuficiência da linguagem: as reticências indicam, afinal, algo que não pôde ser expresso através de palavras — ou seja, as palavras faltam, falham, não dão conta da realidade, que as transcende. 
E. M. Moraes

Do rebentar da imagem: releitura do epílogo de Uma faca só lâmina (1955) a partir da reavaliação da fortuna crítica cabralina ver a tragédia da representação mas também ilumina o parco e pobre "dizível" no seio do "interdito".

Não à toa, na década seguinte, Secchin, em João Cabral: a poesia do menos [1982], referenda a interpretação de Merquior:

\begin{abstract}
Haveria aí uma confissão do fracasso da linguagem? Não exatamente. O que se diz é que a realidade é inapreensível, não se esgota em nenhuma de suas manifestações. Em João Cabral, o discurso poético, renunciando ao silêncio ou à autocomemoração, traduz, assim, a aproximação, parcial e possível, de um horizonte de incompletude, que persiste sempre em aberto. Por isso, na tentativa de atingi-lo, qualquer palavra será pouca e pequena — "toda imagem rebenta”. (SECCHIN, 2015, p. 140).
\end{abstract}

Ao citar o último verso do poema, Secchin acaba por enfatizar a menor intensidade da linguagem em contraste com a intensidade da lembrança consoante, portanto, com o conteúdo da antepenúltima estrofe. Ou seja, porque menos intensa, a imagem rebenta, isto é, parte-se, rompe-se, quebrase com violência, ou, ainda, exaure-se.

Diante disso, é lícito afirmar que os principais críticos que se detiveram em Uma faca só lâmina enfatizaram os limites, i.e., a impotência relativa, não apenas da linguagem poética mas da linguagem tout court, em detrimento do poder da linguagem. Trata-se de abordagem bastante adequada, uma vez que em Cabral o "sim" é uma ilha cercada de "não" por todos os lados. Não obstante, tenciono reavaliar o verso final de modo a deslocar a ênfase do "não" rumo ao "sim".

Em "João Cabral: Filosofia e Poesia" [2000], Nunes detém-se novamente, após quase três décadas, em Uma faca só lâmina a fim de exemplificar o processo pelo qual o uso sistemático de nomes designativos de objetos concretos catalisa um desdobramento encadeado de comparações. Segundo o crítico-filósofo, "os termos comparantes desempenham, por assim dizer, uma ação catalizadora na gestação das imagens” (NUNES, 2007, p. 131). A destacar que, embora mencione "gestação das imagens", o autor não relaciona essa metáfora ao verso final do poema, sobre o qual nada comenta. Coincidência ou não, tal metáfora está em linha com a releitura que ora proponho. Essa proposta decorre da polissemia do verbo "rebentar", cujas acepções podem ser divididas em dois grupos principais a partir de um critério semântico e, em alguma medida, de um critério sintático (predicação verbal). No primeiro grupo, único em que é possível o uso transitivo direto do verbo, encontram-se acepções semanticamente associadas a "morrer", "aniquilar", "ceder", "não dar conta", "não resistir". São exemplos ${ }^{12}$ : "O cansaço rebentou

Revista Letras,

Curitiba, UFPR,

n. 102, pp. 94-115,

jul./dez. 2020

ISSN 2236-0999

(versão eletrônica)

12 Todos os exemplos foram retirados do dicionário online Michaelis. 
o animal"; "A corda, esticada demais, rebentou"; e "As águas rebentaram a comporta. O enorme dique rebentou." ${ }^{3}$. São acepções, em geral, de conotação negativa, pois designam uma falta, constatam insuficiência ou limite. Já no segundo grupo, o uso transitivo direto não é, de modo algum, possível: há incidências de transitividade indireta, embora raras, pois o uso intransitivo do verbo é predominante. O campo semântico vigente é diametralmente oposto ao anterior: "vir a ser", "nascer", "brotar", "desabrochar", "soar com força”. Aqui a conotação é positiva - trata-se de um manifestar-se na máxima intensidade: "Ao anoitecer, as luzes da cidade rebentaram, num espetáculo grandioso"; "Deitou ramos, criou folhas, rebentou em flores. Rebentara, viçoso, o milharal"; ou "Do meio da multidão rebentou um grande grito".

Contudo, sequer seria preciso recorrer a fontes externas a fim de exemplificar o segundo grupo, pois tais acepções podem ser extraídas da própria obra cabralina, mais precisamente das únicas duas incidências do verbo "rebentar" anteriores a Uma faca só lâmina: "As amadas rebentam nas fontes do poema" (“As amadas", 1997a, p. 7) e "Mas é no papel / no branco asséptico, / que o verso rebenta." (“O poema”, ibid., p. 42). Convém notar que, em ambos os casos, há um adjunto adnominal de lugar que associa o espaço do poema ao campo semântico de nascedouro, fonte, origem: "nas fontes do poema" e "no papel/ no branco". Além disso, em todas as incidências (na Faca inclusive), tem-se o uso intransitivo do verbo, de modo que se pode afirmar que estamos diante de um "sim", ou, para dizê-lo cabralinamente: trata-se de um "rebentar" não só de "de morte" mas também "de vida".

Vale destacar ainda que, em muitos outros poemas, há equivalentes semânticos desse "rebentar de vida", sobretudo por meio de um sinônimo que ainda não havia sido mencionado aqui justamente por sua ambiguidade intrínseca. Trata-se do verbo "explodir", que no senso-comum talvez esteja mais associado à morte do que à vida ${ }^{14}$, o que certamente não é o caso em Cabral:

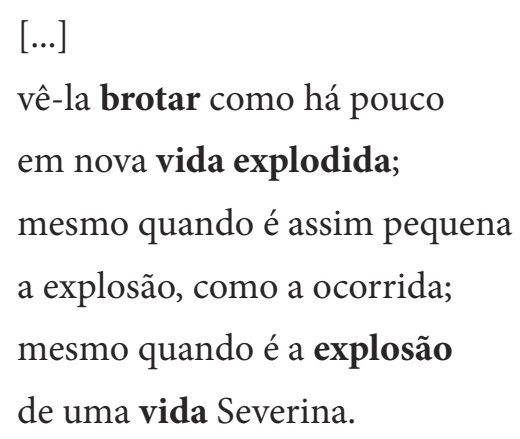

13 Nos dois últimos exemplos, há verbos cujo sentido é negativo a despeito do uso intransitivo. Assim, pode-se afirmar que o uso intransitivo é comum dos dois grupos, ao passo que o uso transitivo é exclusivo das acepções do grupo de conotação negativa.

14 Como contraexemplos se poderia pensar no Big Bang ou na explosão do zigoto em milhões de novas células. Em ambos os casos, trata-se evidentemente de um "explodir de vida". 
E. M. Moraes

Do rebentar da imagem: releitura do epílogo de Uma faca só lâmina (1955) a partir da reavaliação da fortuna crítica cabralina
(“Morte e Vida Severina”, 1997a, p. 180, grifos meus)

$[\ldots]$

o rumor

da oculta fábrica

que cria as coisas

o oculto impulso

que explode em coisas

(“A Árvore”, 1997a, p. 43, grifos meus)

Flor é o salto

da ave para o voo;

o salto fora do sono

quando seu tecido

se rompe; é uma explosão

posta a funcionar,

como uma máquina,

[...]

(“Antiode", 1997a, p. 69, grifos meus)

Um toro de lidia é como um rio

na cheia. Quando se abre a porta,

que a custo o comporta, e o touro

estoura na praça, $[. .$.

(“El toro de Lidia”, 1997b, p. 71, grifos meus)

Cabe aqui uma ressalva. Afinal, justamente porque Cabral não é (nem nunca foi) um poeta dogmático, torna-se imprescindível destacar que, em sua poesia, vida e morte são indissociáveis. Assim como Descartes alcança a máxima certeza através da dúvida mais radical, também no poeta da pedra os extremos convergem. No primeiro grupo de acepções do verbo "rebentar", a negatividade está associada à constatação de um limite. Contudo, essa associação também se dá no segundo grupo, do "rebentar de vida". Isso porque "manifestar-se na máxima intensidade" não é senão manifestar-se no limite. O touro que na praça estoura, isto é, explode, isto é, rebenta, manifesta-se em todo o seu esplendor. Não por acaso, ele "é como um rio na cheia", ou seja, um rio que, por atingir seu limite, mal cabe em si - ou, melhor ainda, um rio que transborda, isto é, que explode para além de suas margens. Já na "Antiode”, o 
tecido do sono se rompe - ou seja, cede, não resiste. Eis o "rebentar de morte". Contudo, justamente esse rebentar do tecido do sono é condição necessária para "o salto da ave para o voo" ou para o desabrochar da flor. Eis aí o "rebentar de vida”. São, portanto, movimentos indissociáveis.

Pode-se dar ainda um passo adiante e destacar a relação entre os verbos rebentar e chocar, que embora não sejam sinônimos quando em estado de dicionário, na poesia cabralina vinculam-se por meio da violência (leia-se intensidade) da vida:

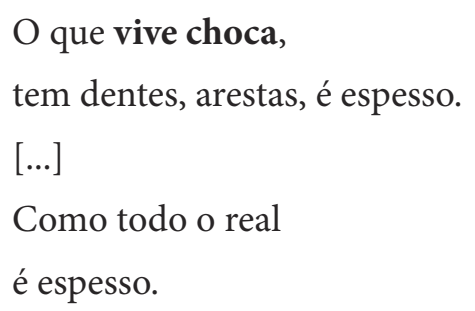

Do que com a coisa que disparam.

(“Ovo de galinha”, 1997a, p. 293-4, grifos meus)

O ovo de galinha ameaça disparar, isto é, chocar, isto é, rebentar a casca que a custo o comporta. Tal qual o ovo, "o que vive choca", ou seja, quebra expectativas, rompe paradigmas. A violência do que é vivo, do que na máxima intensidade se manifesta, reúne todas essas imagens sob a égide do rebentar a barreira entre o "não" e o "sim", i.e., do rebentar limites, sejam eles estéticos, morais, físicos ou mesmo ontológicos.

Há, por último, três poemas coligidos em Museu de tudo - logo, cronologicamente posteriores a Uma faca só lâmina - em que essa indissociabilidade se torna ainda mais patente ${ }^{15}$ :

15 Nesse sentido, pode-se dizer que os livros posteriores a A educação pela pedra implicam não o abandono do projeto anterior (como acredita Santiago), mas justamente o contrário: fazem jus a ele na medida em que se dão a ver mais nitidamente certas marcas da poesia cabralina desde sempre presentes, mas talvez apenas "em estado de semente", motivo pelo qual haviam passado despercebidas ou ignoradas pela crítica. Nos livros derradeiros, pode o autor enfim "explodir suas sementes", de modo que um exercício interessante é ler a obra pré-1966 à luz da produção posterior. 
E. M. Moraes

Do rebentar da imagem: releitura do epílogo de Uma faca só lâmina (1955) a partir da reavaliação da fortuna crítica cabralina

\section{EL CANTE HONDO}

\author{
This is the way the world ends \\ Not with a bang but a whimper
}

T. S. Eliot

O cante hondo às mais das vezes

desconhece essa distinção:

o seu lamento mais gemido

acaba em explosão.

Tão retesada é sua tensão,

tão carne viva seu estoque,

que ao desembainhar-se em canto

rompe a bainha e explode.

(Museu de Tudo, 1997b, p. 47, grifos meus)

\section{CARTÃO DE NATAL}

Pois que reinaugurando essa criança pensam os homens

reinaugurar a sua vida

e começar novo caderno,

fresco como o pão do dia;

pois que nestes dias a aventura

parece em ponto de voo, e parece

que vão enfim poder

explodir suas sementes:

que desta vez não perca esse caderno sua atração núbil para o dente; que o entusiasmo conserve vivas suas molas, e possa enfim o ferro comer a ferrugem,

o sim comer o não.

(ibid., p. 90, grifos meus)

Revista Letras, Curitiba, UFPR, n. 102 , pp. 94-115, jul./dez. 2020 ISSN 2236-0999

(versão eletrônica) 


\section{DUPLO DÍPTICO}

Para este a vida não foi feita

para ser guardada em cofre.

Guardada dentro dele, a vida

é presença que em tudo explode.

$[\ldots]$

De osso: mas caroço e explosivo

com toda a explosão da semente,

Levando sua planta futura

viva e mais, latejadamente.

Se este descuida a menor fresta

a vida explode, extravasada,

como a explosão de uma romã,

que em espanhol se diz granada.

(ibid., p.66-7, grifos meus)

"El cante hondo" vai de encontro à distinção proposta nos versos de Eliot que lhe servem de epígrafe. Vai também na contramão de críticos que julgam ser a obra cabralina uma poesia dogmática, de lógica negativa e excludente. No poema, vigora justamente a dúvida, a total indissociabilidade entre o gemido e a explosão. A notar que, no poema de Eliot, o gemido (whimper) associa-se à morte, uma vez que é com um gemido que o mundo acaba, ou seja, que ele morre. O termo negado é a explosão (bang), que justamente por negação - passa a estar associada ao nascimento - qual na teoria científica do nascimento do mundo (Big bang). O cante hondo, objeto que Cabral elege - e, na medida em que elege, elogia -, é precisamente aquele em que tal distinção é suspensa. Trata-se de um movimento próprio de toda a obra cabralina: em "El cante hondo", o "rebentar de morte" (gemido) cede lugar ao "rebentar de vida" (explosão) exatamente como - para citar outro exemplo anterior a 1966 - em "Morte e Vida Severina", o retirante Severino, cansado de resistir, prestes a rebentar e "saltar fora da ponte e da vida", é dissuadido pela vida mesma, que "rebenta" em nova vida, ainda que precária e provisória.

À luz dessas considerações, proponho reler o "rebentar da imagem" no verso final de Uma faca só lâmina não só como um "rebentar de morte" mas também "de vida”. Para isso, deve-se observar a configuração espaço-temporal do processo de apreensão do real subjacente ao poema: no nível mais alto está 
E. M. Moraes

Do rebentar da imagem: releitura do epílogo de Uma faca só lâmina (1955) a partir da reavaliação da fortuna crítica cabralina o inefável, a realidade rarefeita e impalpável; em seguida, há a lembrança, que já é, ela mesma, imagem da coisa-em-si; a bala, por sua vez, é a imagem dessa imagem - logo, imagem de segundo grau; o relógio é, por sua vez, imagem da imagem da imagem, e a faca, imagem de quarto grau. Na contramão da escala platônica, segundo a qual a imagem mais adequada é a mais imediata — ou seja, a imagem é tanto mais fiel a seu modelo quanto mais próxima dele estiver na "linha sucessória" - , no poema a imagem que melhor traduz o real é justo aquela que mais dista tanto no tempo quanto no espaço.

A lição não consiste, portanto, em que as imagens fracassam por não darem conta de apreender o real em toda a sua força, mas no exato oposto: o real é impalpável por natureza - inapreensível senão através da linguagem, que confere corpo, carne, ao que, inefável, não se deixa apreender imediatamente. Ou seja, trata-se de um elogio ao poder da linguagem, sem, contudo, recair no triunfalismo. Isso porque no horizonte permanece a ressalva de que a apreensão é sempre contingente, provisória. A esta altura, torna-se lícito estabelecer um paralelo entre imagem e vida: ante a violência do real, não será melhor saltar fora da ponte e da vida rumo ao silêncio da morte? Não será lutar com palavras a luta mais vã, uma vez que a caça às imagens é, como diz Benedito Nunes, "sempre deceptiva"? A essa pergunta talvez não haja melhor resposta do que o espetáculo da linguagem: vê-la desfiar seu fio no rebentar das imagens de Uma faca só lâmina. 


\section{Referências}

BARBOSA, João Alexandre. A poesia crítica de João Cabral. In: Alguma crítica. Cotia: Ateliê, 2002.

BENJAMIN, Walter. O conceito de crítica de arte no romantismo alemão. Tradução de M. Seligmann-Silva. São Paulo: Iluminuras, 1993.

CAMPOS, Haroldo de. O geômetra engajado. In: Metalinguagem \& outras metas. São Paulo: Perspectiva, 2006.

CARDEAL, Rafaela. VISITA AO MUSEU DE TUDO, DE JOÃO CABRAL DE MELO NETO. Palimpsesto - Revista do Programa de Pós-Graduação em Letras da UERJ, [S.1.], v. 15, n. 22, p. 462-465, jun. 2016. ISSN 1809-3507. Disponível em: https://www.e-publicacoes.uerj.br/index.php/palimpsesto/ article/view/35025. Acesso em: 14 maio 2020.

FIUZA, Solange. Textos fundadores da recepção crítica luso-brasileira de João Cabral de Melo Neto. Navegações, v. 12, n. 1, p. e32561, 8 ago. 2019.

LIMA, Luiz Costa. Lira e antilira: Mário, Drummond, Cabral. 2. ed. revista. Rio de Janeiro: Topbooks, 1995.

MELO NETO, João Cabral de. Serial e Antes. Rio de Janeiro: Nova Fronteira, 114 1997a.

A educação pela pedra e depois. Rio de Janeiro: Nova Fronteira, 1997b.

MERQUIOR, José Guilherme. Nuvem civil sonhada. In: . A astúcia da mímese: ensaios sobre lírica. 2. ed. Rio de Janeiro: Topbooks, 1997.

MICHAELIS. Moderno Dicionário da Língua Portuguesa. Disponível em: http://michaelis.uol.com.br/busca?id=Xp3nG/. Acesso em: 20 fev. 2019.

NUNES, Benedito. João Cabral: a máquina do poema. Brasília: EdUnB, 2007.

OLIVEIRA, Waltencir Alves de. O gosto dos extremos: tensão e dualidade na poesia de João Cabral de Melo Neto, de 'Pedra do sono' a 'Andando Sevilha'. 2008. Tese (Doutorado em Teoria Literária e Literatura Comparada) - Faculdade de Filosofia, Letras e Ciências Humanas, Universidade de São Paulo, São Paulo, 2008. doi:10.11606/T.8.2008.tde-11092008-171636. Acesso em: 14 jun. 2020. 
E. M. Moraes

Do rebentar da imagem: releitura do epílogo de Uma faca só lâmina (1955) a partir da reavaliação da fortuna crítica cabralina
SANTIAGO, Silviano. O entre-lugar do discurso latino-americano. In: Uma literatura nos trópicos: ensaios sobre dependência cultural. 2. ed. Rio de Janeiro: Rocco, 2000.

As incertezas do sim. In: Vale Quanto Pesa: ensaios sobre questões político-culturais. Rio de Janeiro: Paz e Terra, 1982.

SECCHIN, Antonio Carlos. João Cabral: uma fala só lâmina. São Paulo: Cosac Naify, 2014.

SISCAR, Marcos. João Cabral e a poesia contemporânea: o drama da destinação. Revista Texto Poético, v. 14, n. 25, p. 610-616, jul/dez, 2018. Disponível em: http://revistatextopoetico.com.br/index.php/rtp/article/ view/527. Acesso em: 30 abr. 2020.

Submetido em:10/09/2020

Aprovado em: 27/10/2020 